\title{
Research of Specialists' Needs for Digital Educational Tools for the Organization of Education of Students with Disabilities
}

\author{
Abdallakh K.M. ${ }^{1}$ Zakrepina A.V. ${ }^{1}$ Filatova I.A.,** \\ ${ }^{1}$ Russian Academy of Education, Moscow, Russian Federation \\ ${ }^{2}$ Ural State Pedagogical University, Yekaterinburg, Russian Federation \\ *Corresponding author. Email: filatova@uspu.me
}

\begin{abstract}
Digitalization of the modern educational environment attracts the attention of specialists in connection with the creation of adapted educational conditions for children with disabilities. Compared to the traditional educational environment the availability of inclusive education for all categories of children with disabilities requires the teacher to possess specific skills in the use of digital resources, opening up new possibilities in presenting the curriculum material and means of applications to practical experience of each student.

To study specialists' needs for digital educational tools in the organization of education of students with disabilities, monitoring was conducted, the results of which were systematized and summarized. It is revealed that with the help of digital tools, an educational organization can solve the problems of managing the educational process, library and project resources; create conditions for choosing effective forms of the educational process, including individualization and inclusive options, as well as work with the families of students promptly.
\end{abstract}

Keywords: digitalization of education, special education, inclusion, introduction in the digital educational

environment, digital competence

\section{INTRODUCTION}

The introduction of digital technologies in human activities has a special impact on their interests, social and labor activity. The organization of modern life is determined by new technologies, virtual forms of communication and employment. In this regard, there is a tendency to develop and improve professional skills constantly, acquire new knowledge and improve competencies, and one of the key skills is orientation in the continuous flow of information and the ability to operate it in practice.

Modern social and public trends require adaptation of all areas of human activity to changing living conditions. In education, this is due to the introduction of the new Federal law No. 273-FZ of 29.12.2012 "On education in the Russian Federation" in 2012, which is characterized by an increase in the number of tasks solved with the help of information and communication technologies, their implementation in the educational process, as well as the development of distance technologies and online learning. According to the Russian pedagogical encyclopedia, the process of introducing information tools based on microprocessor technology, as well as information products and pedagogical technologies based on these tools, into educational institutions is called informatization [2]. Today, educational institutions at all levels are equipped with the necessary computer technics, and teachers have completed courses on the use of information and communication technologies in the educational process.

The widespread use of computer technologies in education makes it possible to use them not only for searching and reproducing information, but also to develop completely new learning resources, which gives grounds for organizing digital education. By digital education, we understand the process of interaction between the one that teaches and the student in a digital educational environment, aimed at achieving educational results [1]. The digital educational environment is a set of information tools, devices, sources, tools, and services presented in a digital format [8].

The content of digital education is in the center of attention all over the world - leading universities create educational Internet resources that enable to get education online, dozens of Internet portals are opened, and it is now possible to get the direct access to open lectures from anywhere in the world. Digital devices surround us 
At the end of 2017, the European Union Education Committee developed an approximate profile of teacher's digital competencies, which includes six areas of application:

Area 1, which focuses on the use of digital technologies in a professional teaching environment;

Area 2, that focuses on developing professional skills in searching, creating, and sharing digital educational resources;

Area 3, which aims to develop the necessary skills for teachers to use digital tools in learning and teaching;

Area 4, which is related to the command of digital tools for evaluating educational outcomes;

Area 5, that aims to use digital tools to enhance educational opportunities for students;

Area 6, which defines the content of the teacher's activities to support the development of digital competence of students [3].

Today, it is important not only to constantly improve the skills and training of teachers in the use of digital educational technologies, but also to create the necessary conditions for their implementation and realization in the workplace. It is also necessary to take into account the tasks set in the national program "Digital economy of the Russian Federation" and the state program "Development of education" for 2013-2020 approved by the Government of the Russian Federation, the project "Modern digital educational environment in the Russian Federation".

In order to identify the need for digital scientific and information resources for specialists, a study was conducted in October-December 2019 in order to organize general education for students with disabilities.

\section{METHODS OF RESEARCH}

The methodological basis of the research consists of the fundamental provisions of the cultural and historical theory of child personality development for the role of the social environment as a condition and source of learning and development (L. S. Vygotsky); scientific views on the structure and functions of the educational environment (I. V. Ermakova, N. I. Polivanova, A. I. Savenkov, A.V. Khutorskoy, V. A. Yasvin, etc.).

Materials and methods. In total, 14,861 educational organizations from 85 regions of the Russian Federation took part in the research, including 619 special (correctional) schools, which is $37 \%$ of the total number of separate educational organizations.

Research methods: the study was conducted in the form of monitoring, using an electronic questionnaire consisting of 13 questions with ready-made answers for the respondents to choose, as well as with the possibility to supplement the answer with their own versions. The monitoring included collecting, summarizing and analyzing the practice of using digital educational tools in 
organizing the educational process for children with disabilities.

The main monitoring criteria are:

1) teaching children with disabilities (including of different nosological groups) in an educational organization;

2) availability of digital learning tools in the educational organization;

3) use of scientific and information resources in the organization of the educational process for children with disabilities:

4) availability of measures for the development of digital competencies of students and teaching staff.

\section{RESULTS AND DISCUSSION}

All the organizations that took part in the monitoring session educate children with disabilities in different organizational settings (special schools/classes/general education classes/home-based education, etc.). The total number of students with whom specialists from the organizations participating in the monitoring session work was 155,685 children. Figure 1 shows the number of students of different nosological groups in educational organizations that participated in the research.

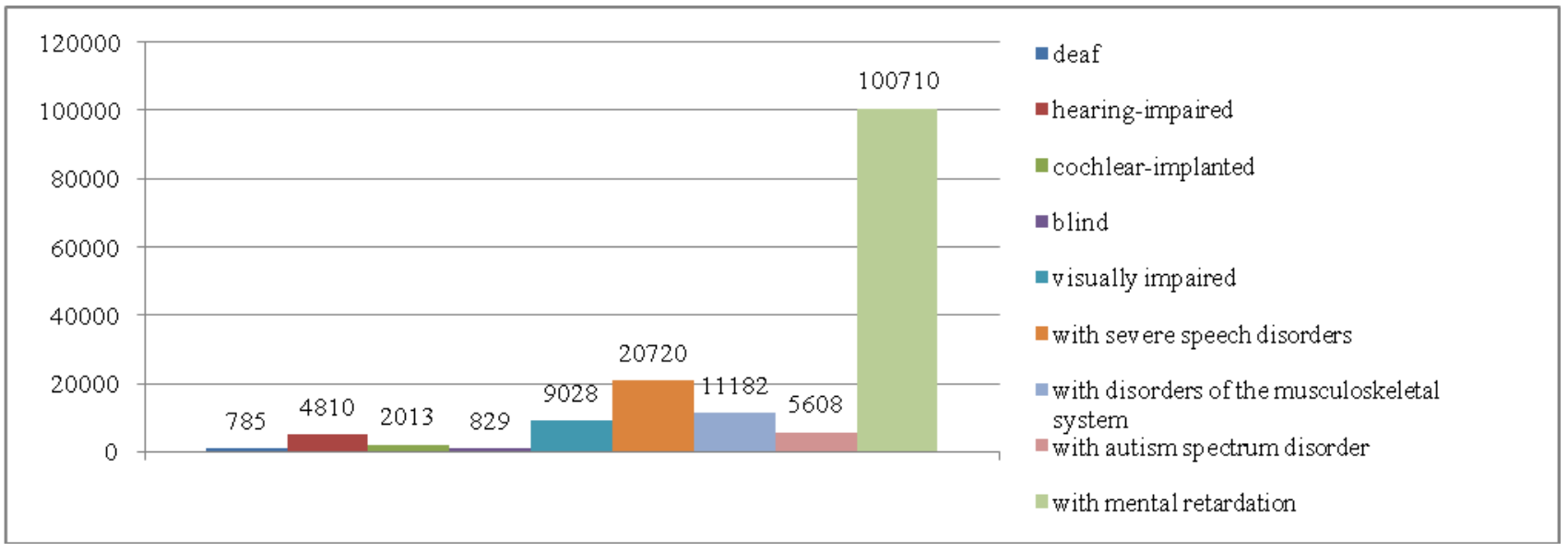

Figure 1 Nosological groups of students

The main part of the research begins with the question of the role of digital technology in the education of students with disabilities. The idea of the negative impact of the digital educational environment as isolating from social life is not supported by most users. Only $1.37 \%$ of the total sample amount indicate the risk of such isolation. Most of the teachers believe that digital resources expand the opportunities for children with disabilities to access social life services ( $48 \%$ of responses) and allow them to form the ability to navigate the flow of information and save time ( $44.5 \%$ of responses).

Some respondents took the opportunity to add their own versions of the answer to the ones already submitted. We divided the results into several groups:

group 1 - new special opportunities (digital technologies provide new opportunities for learning the material, enable to form modern competencies, expand life competencies, etc. );

group 2 - communication (network communication, distance learning; socialization, adaptation, communication, development of communicative skills, etc. .);

group 3 - career guidance (may be a field for professional activity, making it possible to get prepared for the further self-determination in choosing a career, giving a possibility of further employment, etc.);

group 4 - distance education (distance interaction of all participants of the educational process, sustaining the knowledge gained within the individual home study, enabling to organize distance interaction, etc.);

group 5 - assistance in learning the content, it improves the quality of education (helping to implement the individual educational environment of the student, motivating to study, information and methodological support of the educational process, etc.).

The analysis of the answers to the question about digital educational tools used in the organization of education showed that the most common digital educational tools are an electronic journal and an electronic diary (36\%), as well as computer training programs addressed to healthy children (22\%) and online testing (18\%). In $7 \%$ of cases, schools have the resources to conduct virtual laboratory work.

Giving the examples of digital educational resources, half of the respondents $(48 \%)$ confused them with information and communication software (printer, computer, etc.), social networks (for example, Vkontakte), or indicated that they do not use digital educational resources. 
The responses given by the respondents in the "Other" column were also divided into several groups:

group 1 - digital educational tools are not used;

group 2 - they do not know what digital educational tools are, they refer information and communication equipment (interactive whiteboards, touch tables, a joystick and a special keyboard for students with disabilities, etc.) to them;

group 3 - they do not have a minimum knowledge of digital educational resources or just have a general idea (the necessary information for parents is posted on the school's website, diagnostic tools for offline testing, dictionaries, encyclopedias, video tutorials, webinars, etc.);

group 4 - they use special digital educational tools addressed to students with disabilities (speech therapy simulator "Del'fa", training computer programs "Live speech", auditory and speech simulators, etc.)

Another $39 \%$ of respondents indicated that they use digital educational platforms addressed to conditionally healthy students (in some cases, they have information for children with disabilities), including Russian e-school, uchi.ru, Yandex-textbook, Iclass.home-edu.ru and others. Among conditionally competent specialists, the most popular are tools for using augmented virtual reality developed for students with disabilities (25.5\%), computer training programs for different nosological and age groups of students with disabilities $(16.4 \%)$, as well as simulators $(15.3 \%)$. As in the previous question, the respondents show little awareness of the difference between electronic and digital educational resources, in some cases referring material and technical equipment (computers, interactive whiteboards, etc.) to the latter - about half of the answers in the line "Other".

The most popular means of visualization are film lessons $(30.6 \%)$, including those prepared by the teachers themselves $(22.5 \%)$ or posted on open educational platforms $(8.1 \%)$, educational films $(17.8 \%)$ and cartoons (18.6\%, of which $2.5 \%$ are prepared by the teachers and students of the school). Ready-made feature films and documentaries are less popular $-8.9 \%$ and $9.6 \%$, respectively.

The main types of digital educational resources, namely hypertexts and educational cognitive podcasts, were the least popular among the respondents when organizing education for children with disabilities. This is due to the fact that $84.8 \%$ of the respondents are not familiar with the possibilities of using them in practice. Among the leaders were online encyclopedias and electronic libraries. When asked about the use of electronic educational resources in their professional activities, the majority of respondents noted that presentations created by a teacher remain the leading interactive learning tool $(23.6 \%$ of responses), followed by photos and drawings from open Internet databases $(21.9 \%)$.
The majority of respondents answered "no" to the question whether the school has the conditions for implementing distance education using computer technology and the Internet, and special educational platforms. 478 out of the 965 schools use mainly public open platforms, such as uchi.ru, Russian e-school, as well as those resources requiring payment, such as "Mobile eeducation", which has the content specially designed for younger students with disabilities.

According to the respondents, free access to information in the digital educational environment is provided to students with disabilities only in 573 schools out of the 9365 , which is about $6 \%$. In $23 \%$ of schools, access to digital educational resources is not provided at all, in 55\% - partially. It is significant that every seventh respondent could not answer this question with certainty.

Most of the schools (about 85\%) are equipped with computers, printers, scanners and flash drives. Fewer than $10 \%$ of educational institutions have modern tools for organizing children's activities in a digital educational environment (only $3.5 \%$ of schools have interactive whiteboards, mobile virtual reality sets, 3D pens and 3D printers). Only 48 schools out of the 9365 use hardware and software systems to create independent virtual excursions.

The teachers recognize that children with disabilities are motivated and interested in using digital educational tools (27\%), as well as admit expanding opportunities for individualization of learning (22.8\%). Only $4.3 \%$ of the specialists do not see a difference between the traditional organization of training and the use of digital equipment in the educational process.

It is significant that the most common "digital educational tools" are an electronic journal and an electronic diary $(36 \%)$, as well as computer training programs addressed to healthy children (22\%) and online testing (18\%). In $7 \%$ of cases, schools have the resources to conduct virtual laboratory work.

According to the experts themselves, the condition for effective implementation of digital educational technologies is their own professional competence in digital education and the use of electronic educational resources $(39.4 \%)$, as well as the development of special adapted educational content (similar to a special textbook) $(21.2 \%)$ and its use to form social and everyday orientation skills $(17.4 \%)$.

\section{CONCLUSION}

The results of our research show a low awareness of specialists working in the field of basic general education about the possibilities of using digital educational tools in the organization of education for children with disabilities. There is confusion between the concepts of "electronic 
assistance for the family of a special child, understanding special educational needs of modern children with disabilities, distance learning courses for teachers, methodological materials for organizing extracurricular work on the subject, self-education in correctional pedagogy and special psychology, etc.

In our opinion, there is a clear need to build a precise knowledge system that would contain open access information about the practical use of digital educational resources in the organization of educational activities. Thus, the monitoring session made it possible to raise the question of the need to search and develop a base matrix of competencies, which will serve as a reliable basis for the most important set of professional competencies needed by a teacher when organizing educational activities with a particular nosological group of students.

http://www.consultant.ru/document/cons_doc_LAW_1 55553 (InRussian).

[5] "On the approval of the program Modern digital educational environment in the Russian Federation "Digital economy of the Russian Federation": Order of the Government of the Russian Federation № 1632-r of 28.07.2017 [“Ob Utverzhdenii programmy Sovremennaya tsifrovaya obrazovatelnaya sreda $v$ Rossiyskoy Federatsii "Tsifrovaya ekonomika Rossiyskoy Federatsii": Rasporyazheniye pravitelstva Rossiyskoy Federatsii ot 28.07.2017 № 1632-r], available at: http://neorusedu.ru/about (In Russian).

[6] Solovyeva, T. A. (2018), "A new approach to managing the results of including children with disabilities in the general education environment", ["Noviy podhod $\mathrm{k}$ uprativlenyu rezultatami vklyucheniya detey s ovz v obrazovatelnuyu sredu"], Vestnik Leningradskogo Gosudarstvennogo Universiteta imeni A.S. Pushkina, No. 4, PP. 231-239.

[7] Uvarov, A. Yu., Geibl, E., Dvoretskaya, I. V. (2019), "Difficulties and prospects of digitalization of education" ["Trudnosti i perspektivy tsifovoy transformatsii obrazovaniya"], Moscow, 343 p.

[8] "On national goals and strategic development objectives of the Russian Federation for the period up to 2024": Decree of the President of the Russian Federation No. 204 of 7 may 2018 ["O natsionalnyh tselyah i strategicheskih zadachah razivitiya Rossijskoy Federatsii na period do 2024": Ukaz Prezidenta Rossiyskoy Federatsii ot 7 maya 2018 g. № 204], available at: http://www.kremlin.ru/events/president/news/57425 (In Russian). 
Federatsii”: Federalniy zakon № 273-FZ: prinyat Gos. Dumoy 21 dekabrya. 2012.: odobren Sovetom Federatsii 26 dekabrya 2012], INFRA-M, Moscow, $54 \mathrm{p}$. 